OPEN ACCESS

Edited by:

Subramaniam Ramanathan, Nanyang Technological University,

Singapore

Reviewed by:

Christian Bokhove,

University of Southampton,

United Kingdom

Kathryn Holmes,

Western Sydney University, Australia

${ }^{*}$ Correspondence:

Steven Martin Turnbull s.turnbull@auckland.ac.nz

Specialty section:

This article was submitted to STEM Education,

a section of the journal

Frontiers in Education

Received: 20 November 2019 Accepted: 10 March 2020 Published: 02 April 2020

Citation:

Turnbull SM, Meissel K, Locke K and O'Neale DRJ (2020) The Impact of Science Capital on Self-Concept in

Science: A Study of University

Students in New Zealand.

Front. Educ. 5:27.

doi: 10.3389/feduc.2020.00027

\section{The Impact of Science Capital on Self-Concept in Science: A Study of University Students in New Zealand}

\author{
Steven Martin Turnbull ${ }^{1,2 *}$, Kane Meissel ${ }^{3}$, Kirsten Locke ${ }^{1,2}$ and Dion R. J. O'Neale ${ }^{2,4}$ \\ ${ }^{1}$ Faculty of Education and Social Work, School of Critical Studies in Education, The University of Auckland, Auckland, \\ New Zealand, ${ }^{2}$ Te Pünaha Matatini, University of Auckland, Auckland, New Zealand, ${ }^{3}$ Faculty of Education and Social Work, \\ School of Learning, Development, and Professional Practice, University of Auckland, Auckland, New Zealand, ${ }^{4}$ Department \\ of Physics, The University of Auckland, Auckland, New Zealand
}

Understanding factors that contribute to students' self-concept in science is an important task in boosting the number of students studying science and retaining students in science fields. A questionnaire was administered to science students at the University of Auckland in New Zealand ( $N=693$ ) to test a theoretical model of science self-concept tied to the work of Pierre Bourdieu. In this model, a student's social capital (i.e., relationships with parents, teachers and peers) and cultural capital (i.e., science related resources) are seen as key determinants of a student's belief that science is a domain in which they can succeed. Results from a Structural Equation Model (SEM) show that, of the factors included in the model, exposure to passionate science teachers during high school was the main predictor of science self-concept for our sample of university science students, while having peers who value science was also found to be important. Interestingly, science-related resources and parents' value of science were not significant predictors of science self-concept, but the number of university generations in the family did have a positive association. Students who self-identified as male had higher levels of science self-concept, even after accounting for social and cultural factors in our theoretical model. Implications of these findings are discussed in the context of the field of science education and Bourdieu's sociological theory.

Keywords: science education, self-concept, social capital, cultural capital, higher education, science capital, habitus, gender

\section{INTRODUCTION}

Much research has been dedicated to understanding who chooses to study science at university, and what factors influence retention and completion of university science degrees. One particular factor that is associated with retention is students' science self-concept. Broadly speaking, self-concept is an individual's perception of their self (Shavelson et al., 1976), while science self-concept relates to a individual's belief regarding their general competency in science (Jansen et al., 2015). Understanding students' science self-concept is important for several reasons. Students who feel that they are good at science are more likely to have better outcomes in science classes (Chang and Cheng, 2008; Peters, 2013; Tighezza, 2014; Uçar and Sungur, 2017), hold aspirations for further study (Mujtaba et al., 2018), and graduate from university (Larson et al., 2015). In turn, graduating from university tends to lead to better life outcomes in general (Oreopoulos, 2007), and greater economic outcomes (Mahoney et al., 2013; Norton and Cherastidtham, 2016). Research on factors 
affecting student's self-concept in science also has important implications for governments, as they seek skilled workers in Science, Technology, Engineering and Mathematics (STEM) to help gain economic prosperity and growth (Pricewaterhouse Coopers Australia, 2015). In New Zealand, the education system is not only charged with producing an increase in the number of skilled workers in STEM domains, but also with producing confident learners. This message is made clear in the official high school curriculum (Ministry of Education, 2007):

The New Zealand Curriculum is a clear statement of what we deem important in education. It takes as its starting point a vision of our young people as lifelong learners who are confident and creative, connected, and actively involved.

A wealth of research has shown that disparities in tertiary science participation exist across the intersection of gender, ethnicity and social class (Reynolds and Johnson, 2011; Meehan et al., 2017). Students from high Socio-Economic Status (SES) backgrounds are more likely to realize tertiary education goals (Reynolds and Johnson, 2011), whilst interest in science also tends to differ across SES, gender (Cheryan et al., 2017), and ethnicity (Wong, 2016). Previous theorists have used metaphors, such as the gender filter (Blickenstaff, 2005) and the smog of bias (KostSmith et al., 2010) that consider the way contextual factors impact on student outcomes. For example, Kost-Smith et al. (2010) argue that gender disparities can not be attributed to one specific factor, but instead there are a range of factors and small effect sizes that combine to produce inequity. Differing levels of selfconcept may be one such factor that contributes to the disparities observed in STEM participation. For example research shows that female students tend to report lower levels of self-concept in mathematics and science (Else-Quest et al., 2013), and gender differences in confidence may persist even when accounting for actual achievement (Ellis et al., 2016).

A student's self-concept does not exist in a vacuum. It is important to consider the factors that relate to students' selfevaluations of their ability in STEM domains. Why do gender, ethnicity, and social class often share a relationship with students' beliefs regarding their competency in science? The goal of this article is to explore the factors affecting science self-concept further, using a theoretical framework that can answer this question. More specifically, we hope to highlight the way in which students' self-concept in science is rooted in societal structures. To do this, we employ the sociological theory of Pierre Bourdieu (Bourdieu, 1984). Recent research has made use of Bourdieu's sociological theory as a framework for understanding the uneven patterns in student interests and pursuits in science (Archer et al., 2013, 2015; Turnbull et al., 2019). Bourdieu's theory enables us as researchers to place individuals in the context of their environment, and to understand how social, cultural, and historical factors structure the world in which individuals live, and the internal dispositions they hold.

The following section outlines Bourdieu's theory in more detail, with specific reference to science capital (Archer et al., 2015).

\section{BOURDIEU AND SCIENCE CAPITAL}

While applications of Bourdieu's sociological theory are wide ranging, it has been increasingly used as a theoretical framework to understand student's experience in science education (Archer et al., 2015). Bourdieu's sociological framework encourages us to explore how resources are distributed across society, and how external structures in society relate to an individual's internal dispositions. According to Bourdieu (1986), resources, or capital, can take various forms; such as economic, cultural, and social. Economic capital refers to an individual's financial resources (e.g., money, investments). Cultural capital refers to an individual's non-financial resources, such as the objects they own (e.g., books, clothing, furniture), or the characteristics they embody (e.g., accent, posture). Bourdieu (1986) defines social capital as that aspect of our relationships with other individuals that enables us to generate economic and cultural capital. With all forms of capital, the value is determined by the field in which it is being used. To give a basic example, owning science books may be of value for someone studying in the field of science, but this is of less value to someone studying opera. Contemporary research has applied Bourdieu's sociology to explore student outcomes in the field of science specifically by using the concept of science capital (Archer et al., 2015). Science capital has been described by Archer et al. (2014) as a:

conceptual device for collating various types of economic, social and cultural capital that specifically relate to science-notably those which have the potential to generate, use, or exchange value for individuals or groups to support and enhance their attainment, engagement and/or participation in science.

Science capital provides a framework that is relatively simple to interpret and can facilitate our understanding of students' access to resources and the value that they derive from them in science. The following section describes the economic, cultural, and social forms of capital that are important to consider when exploring student's self-concept in science. We begin by describing the importance of financial assets (economic capital) and nonfinancial assets (cultural capital) in education. We then describe the importance of shared relationships with others (social capital) which can provide access to resources. We summarize these social relationships in terms of teachers, peers, and family. We finish this section with a discussion of how these resources relate to the way in which students may view themselves in the field of science through Bourdieu's concept of habitus and the psychological construct of self-concept.

\section{Economic and Cultural Capital}

Simply put, the concept of economic capital refers to an individuals' financial assets (e.g., money). The benefits of economic capital are well studied and relatively easy to interpret. Previous research has shown that family income and wealth are large predictors of educational success (Blanden and Gregg, 2004; Shapiro et al., 2013). In New Zealand, a 30 year longitudinal study conducted by Gibb et al. (2012) found that childhood family income is a strong predictor of educational achievement 
in later life. As outlined by Bourdieu (1986), the value of economic capital comes from its exchange value. For example, students from economically wealthy families are likely able to afford books, laptops, and other aids to study. In paying for these objects, students are exchanging economic capital for nonfinancial assets. Bourdieu categorizes these non-financial assets under the term cultural capital, and it is through cultural capital that educational advantages are accumulated. Recognizing the role of non-financial forms of capital, and with it the social relationships that facilitate access to capital, is complex. In doing so, however, we are able to develop a theoretical model of social class that takes into account factors beyond economic wealth.

Cultural capital refers to the non-financial resources an individual has at their disposal (Bourdieu, 1986). Cultural capital is a complex concept as it is manifested in the objects that one owns (e.g., books, furniture, clothing), or embodied (e.g., in our posture, accent, bodily physique). In the context of science, cultural capital may take the form of objects that are used, such as chemistry sets, laptops, or books. Students may also boost their cultural capital in science with access to other science-related resources, such as visiting science museums (Dawson, 2014) or after-school science clubs (Mujtaba et al., 2018). Cultural capital can play an important role in students' progression to university study (Aschaffenburg and Maas, 1997). This is echoed in the field of science education, where research has found that access to science related cultural capital is associated with decisions to study science further in high school (Mujtaba et al., 2018), and at university (Lyons, 2006).

The manner in which students embody their cultural capital may also carry different value in science. Scientists are typically viewed as old, white males (Nosek et al., 2009; Barthelemy et al., 2016) and individuals who differ from this stereotype may face barriers to acceptance in the field (Ong, 2005). Research has shown that women tend to be viewed as less competent in science solely in terms of their gender in many different roles, whether it involves a student's application to a lab assistant role (MossRacusin et al., 2012), or students' evaluation of their science teachers quality (Potvin and Hazari, 2016).

\section{Social Capital}

While economic and cultural capital are important factors to consider in relation to self-concept, social capital is especially important. Social capital refers to value that is gained through relationships with others. This value can be viewed in terms of the economic and cultural capital that can be mobilized through relationships, but also through the impact of relationships on students internal dispositions (Adler and Kwon, 2017). Having social relationships with individuals who hold valuable forms of capital is highly beneficial. For example, for a student studying at university, having parents who also studied at university may lead to better outcomes. These students are not only more likely to have access to educational resources (objectified cultural capital), but they may also be exposed from an early age to an academic way of life (embodied cultural capital). The following section details three valuable sources of social capital for students studying science: teachers, peers, and family.

\section{Teachers}

One of the most important forms of social capital for students is the student-teacher relationship. The value of this relationship is derived from several factors. Firstly, the content knowledge that teachers hold is an important form of cultural capital for students (Goldhaber and Brewer, 2000; Wayne and Youngs, 2003; Keller et al., 2017), as it gives students access to knowledge. Students who have access to teachers with more content knowledge are more able to derive value from their relationship. However, it is also important to consider that content knowledge is transmitted as a function of the quality of the student-teacher relationship. The attitudes and behaviors of teachers can significantly impact on the interest students hold in STEM (Keller et al., 2017) and the way in which students see themselves in science. As outlined by theorists such as Bandura (1986) and Siegle and McCoach (2007), teachers can boost their student's belief that science is somewhere that they belong by encouraging them and recognizing their ability. For example, students who feel recognized as being good at physics are more likely to hold further interest in physics (Hazari et al., 2017). Through a Bourdieusian lens, recognition provides a signal to students that the field is somewhere they belong. Studies of classroom environments have continuously shown that positive teacher-student interactions are a strong source of interest in science (Osborne et al., 2003; Keller et al., 2017). Mujtaba et al. (2018) found that encouragement was an especially important influence in students aspirations to study chemistry. The social capital provided by teachers may be particularly important for students choosing to study in fields where they are members of an underrepresented group, or where their capital is undervalued by those with power in the field.

\section{Peers}

It is also important to consider the impact of students' social relationships with their peers in science outcomes (Osborne et al., 2003). Adolescence is a time where individuals begin to be increasingly influenced by their peers (Douvan et al., 1966), which can impact on academic engagement and achievement (Ryan, 2000) and students may be subjected to group norms that influence the decisions they make about future study (Brown et al., 1986). Following this, it is no surprise that individuals belonging to friendship groups that value science are more likely to have motivations to pursue science further (Robnett and Leaper, 2013). Other research shows that students' persistence in STEM domains at university may be influenced by their academic peer groups (Ost, 2010).

\section{Family}

Finally, students' social capital is bolstered by their relationships within the family. Parents' educational expectations for their children is a key predictor of educational aspirations ( $\mathrm{Wu}$ and Bai, 2015). In science, Lyons (2006) found that parents' attitudes toward educational qualifications and encouragement were important factors relating to students' decisions to study science. Students with highly educated parents are also much more likely to fulfill goals of attaining tertiary qualifications (Reynolds and Johnson, 2011), while students with parents who are employed in STEM occupations are more likely to choose to 
major in STEM at university (Moakler Jr and Kim, 2014). These findings point to Bourdieu's concept of social reproduction, where the social position of families are transferred across generations. Parents who are university educated may be more likely to engage in the concerted cultivation of children-the process of deliberately building cultural capital that is valued by educational institutions (Lareau, 2011). Parents from higher SES backgrounds may hold higher educational expectations for their children (Carolan and Wasserman, 2015), whilst they may also be more involved in their children's education (Cheadle and Amato, 2011). Beyond the deliberate cultivation of their children, parents who studied science at university are also more able to use science-related discourse which is an important manifestation of cultural capital (Bernstein, 1971; Lyons, 2006) ${ }^{1}$. The role of the family goes beyond typical forms of social capital, as the family provides the context in which individuals develop their identity. For this reason, family-related factors can be strongly tied to Bourdieu's concept of habitus.

\section{Habitus}

As previously discussed, students' experiences within fields and their interactions with resources may begin to be embodied physically as embodied cultural capital. At the same time, students also embody these experiences mentally. The mental embodiment of capital can be summarized by Bourdieu's concept of habitus. Bourdieu defines habitus as the internal dispositions that an individual holds that generate practices within the field. While an individual's volume of capital may determine their position in the field, their habitus determines their disposition toward the field (Bourdieu and Wacquant, 1992). Habitus represents an individuals internalization of society-the resulting mental structure of the process commonly referred to as socialization (Nash, 1999).

For Bourdieu, habitus is the mechanism which mediates between structure and agency. Students internalize the environment in which they are placed and make judgements on what is possible and realistic "for them." A student's family background is likely to have an integral role in shaping habitus. Students from families that are familiar with university or that have a history of working in science related fields may be more likely to have internalized dispositions that see science as something that is for them. A student's habitus is influenced by their familial context (Dimaggio, 1982), with some theorists pointing to the concept of "family habitus" as a tool to understand how family resources, values, and lifestyle choices are internalized by children (Tomanović, 2004; Archer et al., 2012). The resources available to students through their family are thus extremely important, not only because they offer objectified forms of cultural capital, but also because they offer exposure to ways of thinking and understanding that have been historically proven to be valued by educational institutions. Students may

\footnotetext{
${ }^{1}$ It is important to note that we do not suggest that the cultural capital espoused by those who are privileged is 'better', only that it carries more value in the field of science education. Even though science is commonly perceived as having a 'culture of no culture' (Traweek, 2009), the ways of teaching, assessing, and valuing student's capital is predominantly defined by those with power in the field of science-historically western, male, and wealthy.
}

be more likely to view science as a realistic study choice, and university as a possible destination, if they have parents who have modeled these trajectories previously (Lyons, 2006).

While family provides the context in which habitus is established, habitus is also informed by broader cultural groupings that individual identify with, and their experiences in other contexts, such as school. Bourdieu (1984, p. 101) stated that if individuals are exposed to "homogenous conditions of existence" (i.e., similar life experiences) individuals will have similar habitus. In this sense, habitus can take on a collective quality where members of the same group are socialized in similar ways, predisposing them to hold similar dispositions. For example, Edgerton et al. (2014) use the concept of gendered habitus to explain how gender socialization relates to gender disparities in educational achievement. Research also suggests that contexts outside of the family, such as school and peer groups, become increasingly important as students progress through education, while the impact of the family may diminish (Holm and Jæger, 2011).

Much research has discussed applications of habitus in education research (Nash, 1999; Reay, 2004), although the concept is often criticized for being too complex (Goldhaber and Brewer, 2000) and difficult to operationalize (Dumais, 2002). Most research on habitus has been qualitative, but, as outlined by $\mathrm{Mu}$ (2014), there is an increasing need to consider quantitative applications of habitus. As habitus represents the internalization of broader social structures, it takes on a collective quality that operates across social groups. While qualitative methods may be more able to describe individual experiences of habitus, quantitative methods are able to explore this collective quality of habitus. The current study operationalizes habitus quantitatively through the use of a science self-concept inventory. The construct of science self-concept was chosen as it is can be theoretically tied to arguments outlined by Bourdieu regarding habitus (Bodovski, 2014; Mu, 2014). The following sections will describe self-concept in more detail and explain its relevance to Bourdieu's theory and the current study.

\section{Self-Concept}

While quantitative applications of habitus in education research are relatively rare, quantitative applications of self-concept have been more widely used, operationalized and validated (e.g., Hattie, 2014; Marsh, 2014). Despite much variety in definitions of self-concept existing in research (Shavelson et al., 1976), selfconcept can be broadly defined as the way in which an individual perceives their self (Shavelson et al., 1976; Rosenberg, 1979). As outlined by Shavelson et al. (1976, p. 488) "Self-concept may be described as: organized, multifaceted, hierarchical, stable, developmental, evaluative, and differentiable." In basic terms, self-concept is an individual's judgement about their general competence in a domain (Jansen et al., 2015), which can be general (i.e., "I am good at school") and specific (i.e., "I am good at science at school"). In many ways, self-concept is thus theoretically similar to habitus. Self-concept (Shavelson et al., 1976, p. 488) and habitus (Nash, 1999) are both multifaceted in that they operate across general and specific domains. They are also both relatively stable (Shavelson et al., 1976, p. 488) and 
durable (Bourdieu, 1984), although both are subject to change when influenced by environmental sources located outside of the individual, such as the appraisals of others (Bong and Skaalvik, 2003).

Although we identify similarities between self-concept and habitus, it is important to note that we do not consider them to be two different technical terms referring to the same underlying construct (a jangle fallacy). While habitus is the internal, deeper "system of dispositions" (Bourdieu, 1984, p. 471) that generates practice, often operating "below the level of consciousness" (Bourdieu, 1984, p. 466), self-concept is a perception one has of their self (i.e., "I am good at science"). While habitus includes domain-specific self-perceptions of competence, it also encompasses an "estimation of chances" (Bourdieu, 1977, p. 76) that guides future practices and dispositions (i.e., "is science for $m e ?$ ?"). Self-concept may be viewed as an aspect of habitus that can be scrutinized through introspection. This point is argued by Bodovski (2014, p. 395), who suggests that we may view both general and area-specific self-concepts as "illustrations of different aspects of habitus."

Despite the conceptual differences between habitus and self-concept, we argue that scores on inventories assessing self-concept can be productively interpreted through a Bourdieusian framework, and this has been evidenced in prior research (Dumais, 2002). As habitus may operate under the surface or unconsciously, it is a difficult concept to measure psychometrically, while self-concept is easier to assess. Importantly, the decision to interpret self-concept in terms of student habitus is necessary as it: "ensures that the research focus is always broader than the specific focus under study" (Reay, 2004). In other words, using the concept of habitus facilitates the understanding of how an individual's self-concept is generated in relation to the socio-cultural context in which an individual lives. Given the similarities between self-concept and habitus, self-concept inventories are an appropriate and useful tool to explore an individual's habitus.

Few New Zealand based studies have explored university students' self-concept or beliefs regarding their academic competency (Dalgety and Coll, 2006; Murphy, 2018). In one such study, Dalgety and Coll (2006) explored the self-efficacy of first year university chemistry students in New Zealand across three time points in an academic year. They found male students tended to report higher scores in specific items related to selfefficacy (for example in their belief that they could achieve a passing grade in a chemical hazards course). While the work of Dalgety and Coll (2006) offers many insights into student's internal dispositions at university in the context of New Zealand, the lack of research in this area, especially within the last decade, is a lacuna to be filled.

\section{The Current Study}

The current study seeks to address these two gaps in the research by exploring the relationship between science capital and selfconcept in science for university students in New Zealand. More specifically, we apply Pierre Bourdieu's (Bourdieu, 1984, 1986) concepts of capital and habitus to explore the interaction between students' access to resources and internal dispositions. Whilst the factors affecting outcomes in science are wide-ranging (Osborne et al., 2003), we focus on the impact of science-related resources and social experiences in science on students' self-concept in science. In doing so, we are able to assess the impact of social class on self-concept, but using a definition of class defined in terms of capital (social, cultural, and economic resources), as opposed to solely economic wealth. Our specific hypotheses are as follows. We expect:

- Higher levels of science-related social and cultural capital to be associated with higher levels of self-concept in science.

- Relationships with high school teachers will be the most important form of social capital. This is based on the idea that teachers are experts in the field and their judgements provide the most domain-specific feedback. In terms of habitus, students will be more likely to internalize the idea that they are good at science if they have an expert (the teacher) encourage them and/or recognize their ability.

- Male students will have higher levels of self-concept than female students. This is based on previous research that points to gender disparities in confidence in science and mathematics (Else-Quest et al., 2013; Ellis et al., 2016).

- The number of university generations within a student's family, and having parents positively orientated toward science will be positively associated with self-concept. We would expect students who have available academic role models in their family to have a habitus that is predisposed to university science study. Such students will be more likely to hold the belief that university is somewhere where they belong, and somewhere that they can be successful, because that is what their family does.

While acknowledging that differences in science self-concept may exist across ethnic groups, the decision was made to exclude ethnicity from the current study. This decision was made to be consistent with kaupapa Māori values, a research position specific to the context of New Zealand that acknowledges the right of Māori (the indigenous population of New Zealand) to self-determination. This means that research concerning Māori should be done with Māori, and for the benefit of Māori (Walker et al., 2006). We seek to acknowledge our responsibility as researchers by elucidating the patterns found in the current study through a separate qualitative research project. This approach enables students from historically marginalized groups, such as Māori and Pasifika, the opportunity to have their own voices heard. This qualitative piece seeks to minimize the risk of deficit-theorizing by allowing for more depth and nuanced understandings of Mãori and Pasifika experiences in science. Future work should consider ways of knowing and constructing science and culture that are grounded in Māori ways of knowing, such as Mātauranga (Hikuroa, 2017). We hope that the results of the current study can aid in this endeavor.

\section{METHODOLOGY}

During the first semester of 2019, an online questionnaire was administered to science students at the University of 
TABLE 1 | Sample description.

\begin{tabular}{lccc}
\hline & N & Count & Percent \\
\hline Male & 685 & 247 & 0.36 \\
Female & 685 & 431 & 0.63 \\
Gender diverse & 685 & 7 & 0.01 \\
Euro & 693 & 367 & 0.53 \\
Asian & 693 & 305 & 0.44 \\
Pasifika & 693 & 28 & 0.04 \\
Māori & 693 & 48 & 0.07 \\
MELAA & 693 & 21 & 0.03 \\
Other ethnicity & 693 & $\mathbf{S}$ & 0 \\
\hline & $\boldsymbol{N}$ & Mean & $\mathbf{S D}$ \\
\hline Age & (** & 19.93 & 3.65 \\
Parent Job (0-4) & 594 & 2.61 & 0.71 \\
Uni generations (0-3) & 681 & 1.67 & 1.04 \\
\hline
\end{tabular}

Counts and percentages of categorical characteristics, and means and standard deviations of ordinal characteristics. Individuals self-reported gender which was then categorized into male, female and gender diverse groups for reporting purposes. Participants were given the option to self-identify with multiple ethnic groups, which means that percentages do not total to 100. *Middle Eastern, Latin American, or African. ${ }^{* *}$ Mature students (those with a recorded age over 24) were excluded from analysis $(n=42) . S$, suppressed due to low cell size.

Auckalnd (UoA) via email following approval from the UoA Human Ethics Committee. In order to boost the rate of response, the questionnaire was designed to be quick (10 min), consisting of 48 items. Questionnaire responses were anonymous, with the exception of students who left their email to be entered into a prize draw. In total, 693 students consented to participation and completed the questionnaire, with a mean age of around 19 years old (the sample is summarized in Table 1).

The questionnaire asked students for factual information about themselves, and also questions regarding five latent constructs informed by and adapted from the work of DeWitt et al. (2011). The constructs, outlined in our conceptual model (see Figure 1), included self-concept in science (Science SelfConcept; 5 items), experience of high school science teacher quality (Science Teachers; 5 items), parental attitudes toward science (Science Parents; 4 items), peer attitudes toward science (Science Peers; 4 items), and access to science-related resources (Science Resources; 5 items). The first four constructs were measured through items asking students to rate their agreement regarding a statement on a Visual Analog Scale (VAS), with scores ranging from 0 (do not agree) to 100 (strongly agree). VAS have been used extensively in past research and have been found to be as valid and easy to use as likert scales (Hasson and Arnetz, 2005). Given the sample population in the current study can be expected to have high scores on the constructs measured (i.e., in general, we would expect students who choose to study science to score highly on science self-concept measures) there is the possibility of a ceiling effect that could occur with likert scales (Chyung et al., 2018). A continuous rating scale was thus used to decrease the risk of a ceiling effect and provide sufficient variance needed for analysis (Chyung et al., 2018). The final construct, access to Science Resources, was measured on a 1-5 scale, where students were asked how often they participated in a science related activity ( 1 being never, 5 being once a week). For all constructs, item statements and loadings can be seen in Table 2. These loadings refer to the extent to which an item relates to the underlying latent construct, and may be interpreted similarly to a correlation (i.e., loadings close to 1 indicate an item strongly loads onto a construct, while loadings closer to 0 are weaker). Other questions asked for factual information, such as gender, ethnicity, family education, and parents' job.

The following variables were included in our analyses:

- Science Self-Concept: We included 5 items from the positive and negative self-concept scales of DeWitt et al. (2011) ("I am good at science", "If I study hard I will do well in science courses").

- Science Teachers: Experience of high school science teachers refers to the extent to which students recall having positive experiences with their high school science teachers. This scale, which included 5 items, refers to the degree of enthusiasm, care and recognition the student perceived.

- Science Parents: Parental attitudes toward science was adapted from the parental attitudes toward science scale of DeWitt et al. (2011) and included 4 items. The item "My parents would be happy if I became a scientist when I grow up" was replaced with "My parents/carers would like it if I worked in science" to better reflect the target population.

- Science Peers: Peer value of science was measured through 4 items adapted from the "Peer orientation toward school" and "Peer attitudes toward science" scales of DeWitt et al. (2011). One item, Q4.1 ("My friends see me as a 'science' person"), did not load on to the construct. It is likely that this construct represents the participants view of their peers, as opposed to the students' subjective experience of their peers perception of them.

- Science Resources: Students' access to resources was adapted from DeWitt et al. (2011) and included 5 items. To suit our target audience, we replace the original phrase "How often do you do the following things when you are NOT in school...", with "Growing up, how often did you...”. One item, Q5.5 ("Growing up, did you go to a lunchtime or after-school science club?") did not load onto the construct. This may be due to the low number of students who responded positively to this question. An important point to consider is that we, as researchers, are defining science-related cultural capital in our own terms. Whilst the items used in the current study are by definition forms of capital, we acknowledge that other forms of capital exist and hold value in different socio-cultural contexts.

- University Generations: University Generations is a count score of the reported number of consecutive generations a participant's family has gone to university. First generation students receive a score of 0 , participants who report having siblings attend receive a score of 1 , participants who report having parents attend university receive a score of 2 , and those 


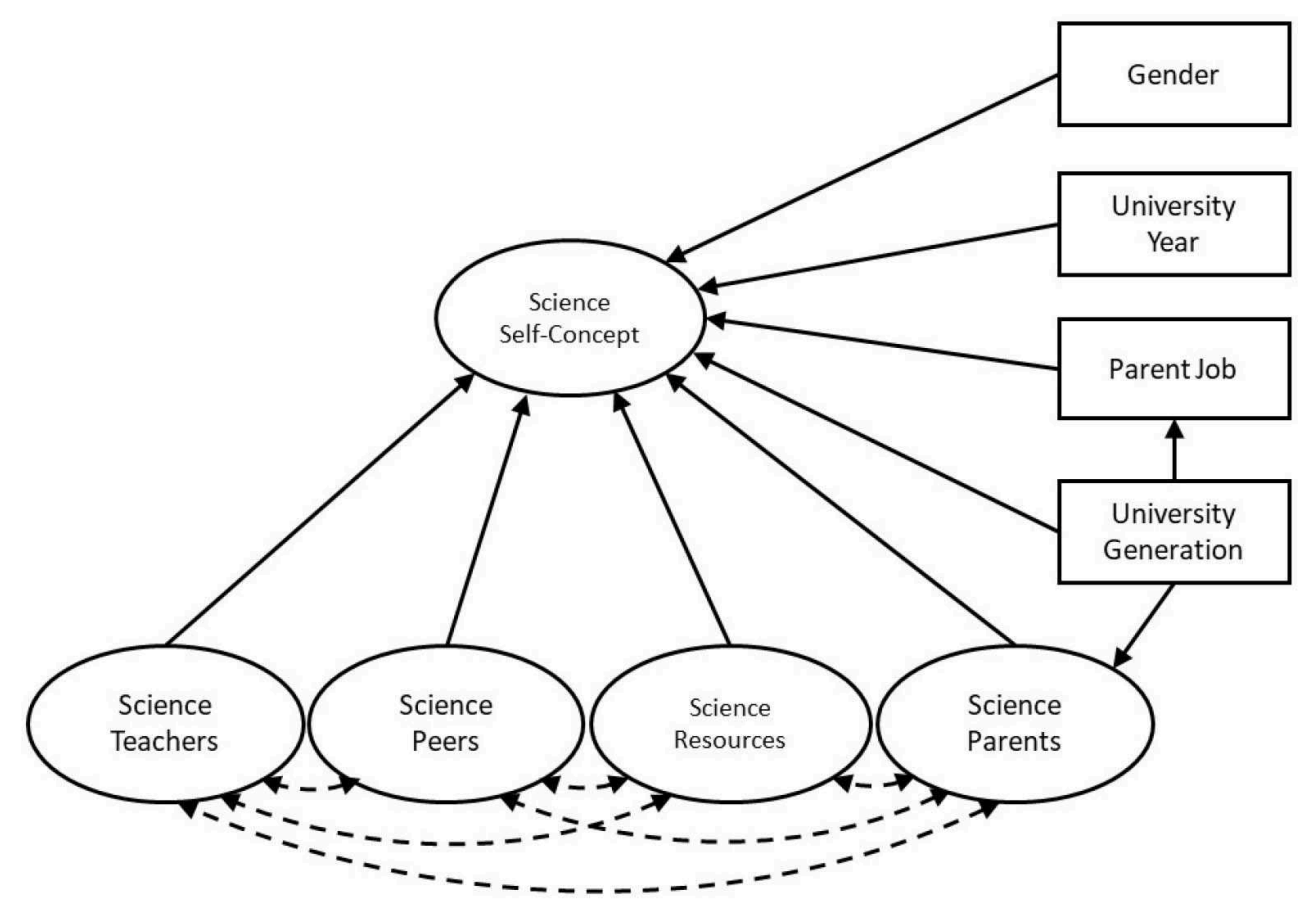

FIGURE 1 | Conceptual Model. Latent variables are represented by oval boxes, observed variables are represented by rectangular boxes. Regressions are represented by one-sided arrows, while correlations are represented by double headed arrows and dashed lines.

who reported having parents and grandparents attend receive a score of 3 .

- Parent's Job: Participants were asked to state the profession of their father/male carer and their mother/female carer. The professions were classified according to the Australian and New Zealand Standard Classification of Occupations (ANZSCO), where a score of 0 is unemployed, 1 is low skilled, and 4 is highly skilled. The Parent's Job score is the maximum value of both parents' scores.

- Gender: Gender was recorded using an open text box, and then categorized according to the classification set out by Statistics New Zealand. Of the 693 students who completed the survey, only $1 \%$ did not record a gender.

Little's MCAR test showed that data could be considered missing completely at random $(p=0.08)$, although patterns of missing data showed that there was attrition bias-questionnaire items tended to have more missing toward the end of the questionnaire. As a robustness check, all models were ran on the imputed and non-imputed datasets. We found that both sets of data had similar model fit, reliability, and relationships between variables. We proceeded to use multiple imputation in order to avoid list-wise deletion of cases with missing data and retain sample size. Missing data for the construct items were imputed using Predictive Mean Matching (PMM) using the MICE package in R (Buuren and Groothuis-Oudshoorn, 2010), as PMM offers a suitable method for dealing with non-normal data (Little, 1988). Cases that were missing scores on at least half the items from a construct (37 cases) were excluded from analysis (e.g., with a construct with 5 items, cases missing scores on 2 items would be kept, whilst cases missing scores on 3 or more items would be excluded). Mature students (those with a recorded age over 24) were also excluded (42 cases) as the measures of social and cultural capital employed are limited to the transmission of capital from parents and high school to university. A further 31 students were excluded from analysis due to missing data on nonimputable variables, such as parent's job, university generations, or gender. Imputation allowed us to retain 174 cases that would otherwise be excluded with list-wise deletion, leaving a sample size of 583 students.

Confirmatory Factor Analysis (CFA) was carried out to test the validity of our latent constructs. Concurrent and convergent validity (Campbell and Fiske, 1959) of these measures were established through CFA, and found to be at an adequate level. We used Cronbach's $\alpha$ and McDonald's $\omega$ to test internal consistency, with both providing similar reliability scores. McDonald's $\omega$ and Cronbach's $\alpha$ were adequate for all constructs ( $\alpha$ ranging from 0.75 to $0.85, \omega$ ranging from 0.74 to 0.86 ), except Science Self-Concept which had an $\alpha$ of 0.68 and an $\omega$ of 0.67 . Whilst 0.70 is usually considered an acceptable level for internal consistency, it has been argued that $\alpha$ below 0.70 are not uncommon for attitudinal scales (Field et al., 2012). The lower internal consistency may also be due to the two negatively worded items (Q1.2 and Q1.5) which had lower loadings compared to the other construct items.

\section{Structural Equation Modeling}

Structural Equation Modeling (SEM) was used to analyse the conceptual model outlined in Figure 1. We chose to use 
TABLE 2 | Questionnaire Items.

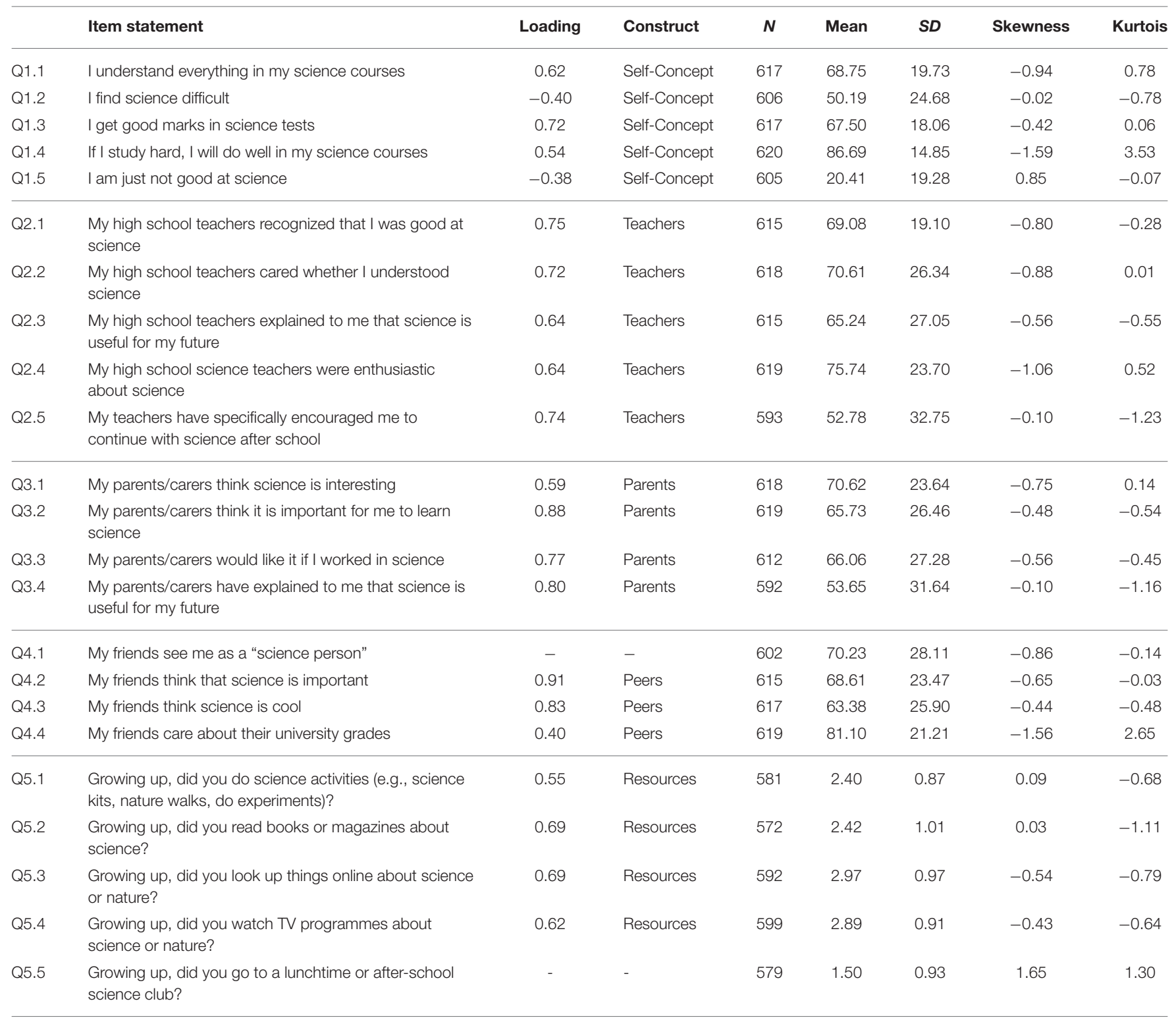

Table showing the questionnaire items used in the current study, with loadings onto the relevant latent construct where applicable. Descriptive statistics for each item are also reported. All items were scored on a continuous scale of $0-100$, with the exception of Q5 items, which were scored on a Likert scale of 1-5.

SEM for several reasons. Firstly, SEM is able to consider hypothetical constructs that are not directly observable (such as self-concept). In practice, this means that we do not derive new variables from questionnaire items through a mean score or aggregated sum. Instead, SEM uses parameter estimates which consider measurement error and covariances between items. This is especially important when we may not expect our items to load on to a latent construct equally. Secondly, unlike simple regression models, SEM is able to model multiple relationships between variables. Doing so enables us to consider many statistical relationships in a single relative context. Finally, SEM is a widely used technique with established guidelines for judging the quality of models (Schreiber et al., 2006), and publicly available software (e.g., Rosseel, 2012).

SEM comprises two parts, the measurement model and the structural model. The measurement model shows the loadings of manifest variables onto each latent construct, while the structural model shows the interrelations between the latent constructs and other variables in the conceptual model (Schreiber et al., 2006). In our model, Science Self-Concept is viewed as a dependent variable, predicted by Science Teachers, Science Peers, Science Parents, and Science Resources. We also include other manifest variables as predictors, including Gender, University Generations, University Years, and Parent Job. We also model correlations between our latent constructs; 
TABLE 3 | Correlations between constructs for CFA.

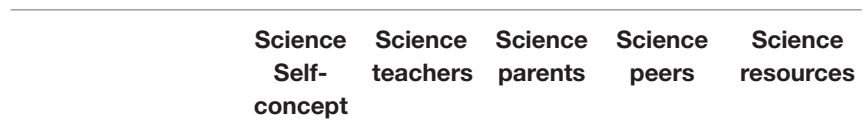

\begin{tabular}{lccccc}
\hline Science self-concept & 1 & - & - & - & - \\
Science teachers & 0.35 & 1 & - & - & - \\
Science parents & 0.21 & 0.31 & 1 & - & - \\
Science peers & 0.26 & 0.30 & 0.49 & 1 & - \\
Science resources & 0.16 & 0.19 & 0.28 & 0.35 & 1 \\
\hline
\end{tabular}

Variables were standardized to have a mean of 0 and a standard deviation of 1. CFA, confirmatory factor analysis. $N=583 ; M=0 ; S D=1$.

in addition, University Generations is modeled as a predictor of Science Parents and Parent Job.

SEM with robust standard errors (Huber, 1967; White, 1982) was carried out on five imputed datasets using the Lavaan (Rosseel, 2012) and semTools (Jorgensen et al., 2018) packages in R ( $\mathrm{R}$ Core Team, 2013). Rubin's rules (Rubin, 2004) were used to pool point and standard error estimates across our imputed data sets.

\section{RESULTS}

Descriptive statistics, including means and standard deviations are summarized in Table 2. Correlations between constructs, shown in Table 3, show that Science Self-Concept was significantly and positively correlated with each form of science capital explored in the current study. Science SelfConcept was most positively associated with Science Teachers $(r=0.35, p<0.001)$, and most weakly correlated with Science Resources $(r=0.16, p<0.001)$. We now detail the results of the SEM which explores the relationships between these constructs while including other factors present in the theoretical model (Figure 1).

We performed a SEM analysis with robust standard errors to test the conceptual model shown in Figure 1 on a sample of 583 undergraduate science students. While the hypothesized model appears to be a tolerable fit to the data $(\mathrm{CFI}=0.904$; $\mathrm{TLI}=0.885$; RMSEA $=0.053$, gamma-hat $=0.928)$, model fit was improved with the inclusion of two modifications. Specifically, we added two additional correlations between items Q2.1 ("My high school teachers recognized that I was good at science") and Q2.3 ("My high school teachers explained to me that science is useful for my future"), and items Q2.2 (My high school teachers cared whether I understood science) and Q2.4 (My high school science teachers were enthusiastic about science). These correlations make sense theoretically, as Q2.1 and Q2.3 may point to possible expectations from teachers, and Q2.2 and Q2.4 may relate more to how personable teachers were. With these modifications, goodness of fit statistics showed acceptable model fit ( $\mathrm{Hu}$ and Bentler, 1999; Steiger, 2007) $(\chi=598.38, \mathrm{df}=258, \mathrm{CFI}=0.93$, TLI $=0.91$, RMSEA $=0.05$, SMSR $=0.05$, gamma-hat $=0.95)$. As shown in Table 4, the standardized loadings were all significant and acceptable.
TABLE 4 | Measurement model.

\begin{tabular}{|c|c|c|c|c|c|c|}
\hline Latent & Manifest & Estimate & $\begin{array}{c}\text { Standard } \\
\text { error }\end{array}$ & $z$ & $p$ & Standardized \\
\hline \multirow[t]{5}{*}{ Science self-concept } & Q1.1 & 1.00 & & & & 0.65 \\
\hline & Q1.2 & -0.80 & 0.11 & -6.99 & $<0.01$ & -0.43 \\
\hline & Q1.3 & 1.03 & 0.09 & 11.00 & $<0.01$ & 0.72 \\
\hline & Q1.4 & 0.61 & 0.07 & 8.80 & $<0.01$ & 0.55 \\
\hline & Q1.5 & -0.60 & 0.08 & -7.70 & $<0.01$ & -0.39 \\
\hline \multirow[t]{5}{*}{ Science teachers } & Q2.1 & 1.00 & & & & 0.75 \\
\hline & Q2.2 & 0.94 & 0.06 & 14.65 & $<0.01$ & 0.70 \\
\hline & Q2.3 & 0.97 & 0.08 & 12.80 & $<0.01$ & 0.72 \\
\hline & Q2.4 & 0.75 & 0.07 & 11.03 & $<0.01$ & 0.62 \\
\hline & Q2.5 & 1.18 & 0.08 & 14.51 & $<0.01$ & 0.74 \\
\hline \multirow[t]{4}{*}{ Science parents } & Q3.1 & 1.00 & & & & 0.59 \\
\hline & Q3.2 & 1.65 & 0.12 & 14.05 & $<0.01$ & 0.88 \\
\hline & Q3.3 & 1.51 & 0.13 & 12.06 & $<0.01$ & 0.77 \\
\hline & Q3.4 & 1.81 & 0.14 & 12.82 & $<0.01$ & 0.82 \\
\hline \multirow[t]{3}{*}{ Science peers } & Q4.2 & 1.00 & & & & 0.93 \\
\hline & Q4.3 & 0.99 & 0.06 & 16.26 & $<0.01$ & 0.82 \\
\hline & Q4.4 & 0.39 & 0.05 & 7.82 & $<0.01$ & 0.41 \\
\hline \multirow[t]{4}{*}{ Science resources } & Q5.1 & 1.00 & & & & 0.56 \\
\hline & Q5.2 & 1.43 & 0.11 & 12.69 & $<0.01$ & 0.69 \\
\hline & Q5.3 & 1.40 & 0.15 & 9.18 & $<0.01$ & 0.69 \\
\hline & Q5.4 & 1.16 & 0.13 & 8.84 & $<0.01$ & 0.63 \\
\hline
\end{tabular}

The measurement model summarizes the loading of items onto theoretical constructs outlined in Figure 1. The results of the measurement model show that items loadings were significant and acceptable.

The structural model, shown in Table 5 and visualized in Figure 2, shows the interrelationships of the latent variables (specifically the impact of constructs on Science Self-Concept) and the other observed variables in our conceptual model.

Results of the structural model show that Science Teachers had the most impact on students' Science Self-Concept with a significant standardized estimate $(\beta)$ of 0.33 . Of the other science capital related constructs, Science Peers was the only other significant predictor of Science Self-concept $(\beta=0.16)$. For the other predictors in our model, the number of university generations in the family (Uni Generations) and identifying as male positively predicted Science Self-concept $(\beta=0.12$ and $\beta=$ 0.17 , respectively). The number of years a student reported being at university (Uni Years) was a significant negative predictor of Science Self-Concept $(\beta=-0.10)$.

\section{DISCUSSION}

Our results show that, while social capital and cultural capital in science are all positively associated with the science selfconcept of university science students, the social relationships shared with teachers and peers are the most important. For university science students, parents' value of science and the science related resources students had while growing up were non-significant predictors of science self-concept. However, the number of university generations within the family did positively 
TABLE 5 | Structural Model.

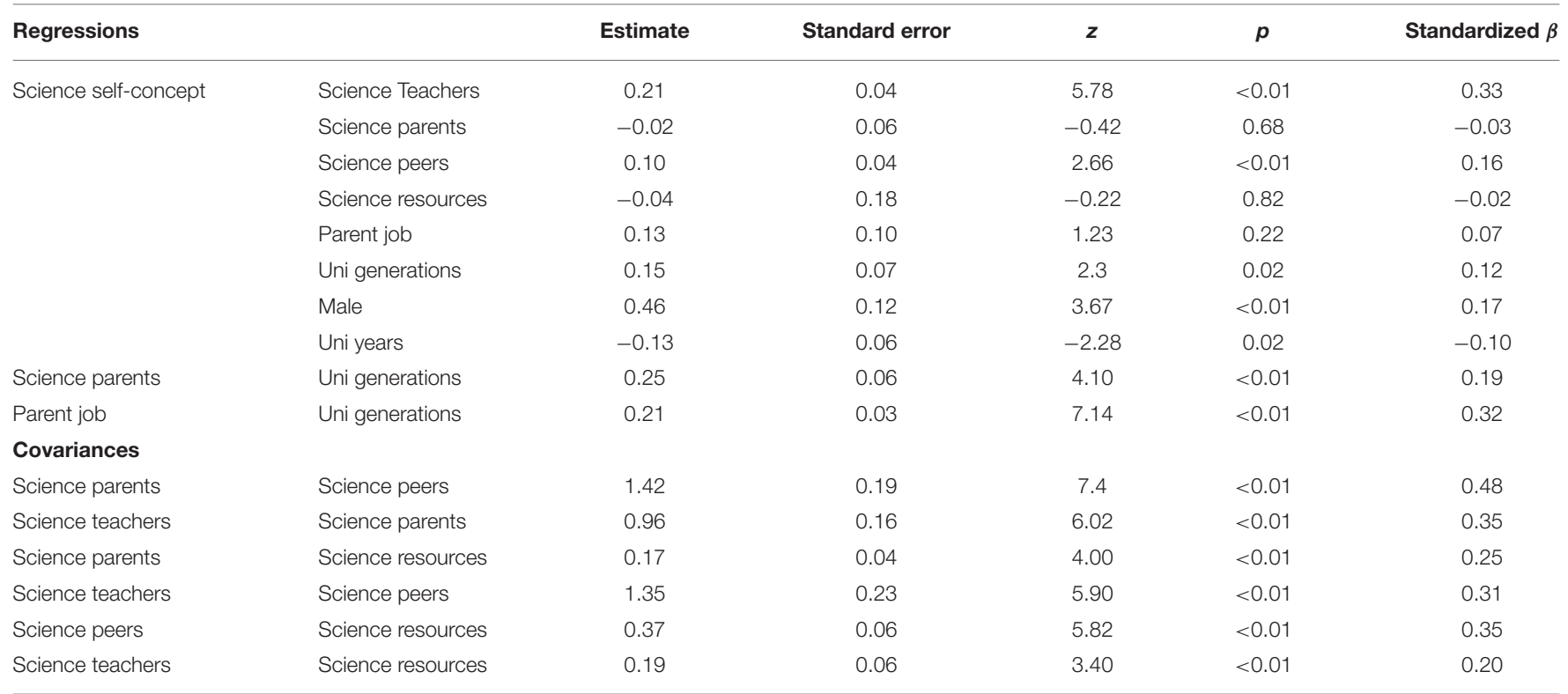

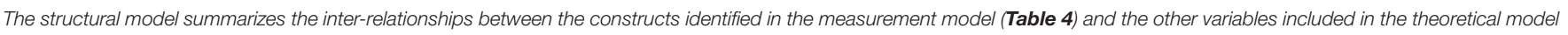

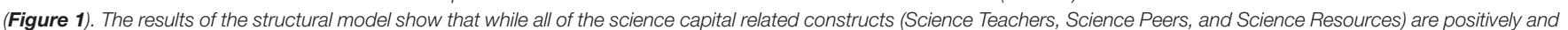

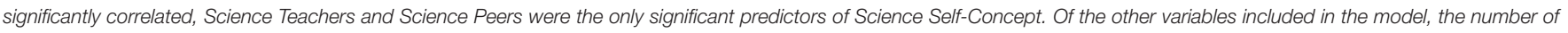

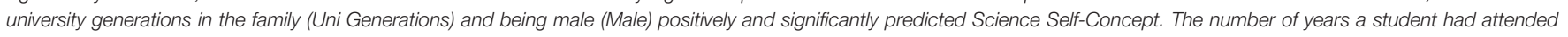
university negatively and significantly predicted Science Self-concept. These results are visualized in Figure 2.

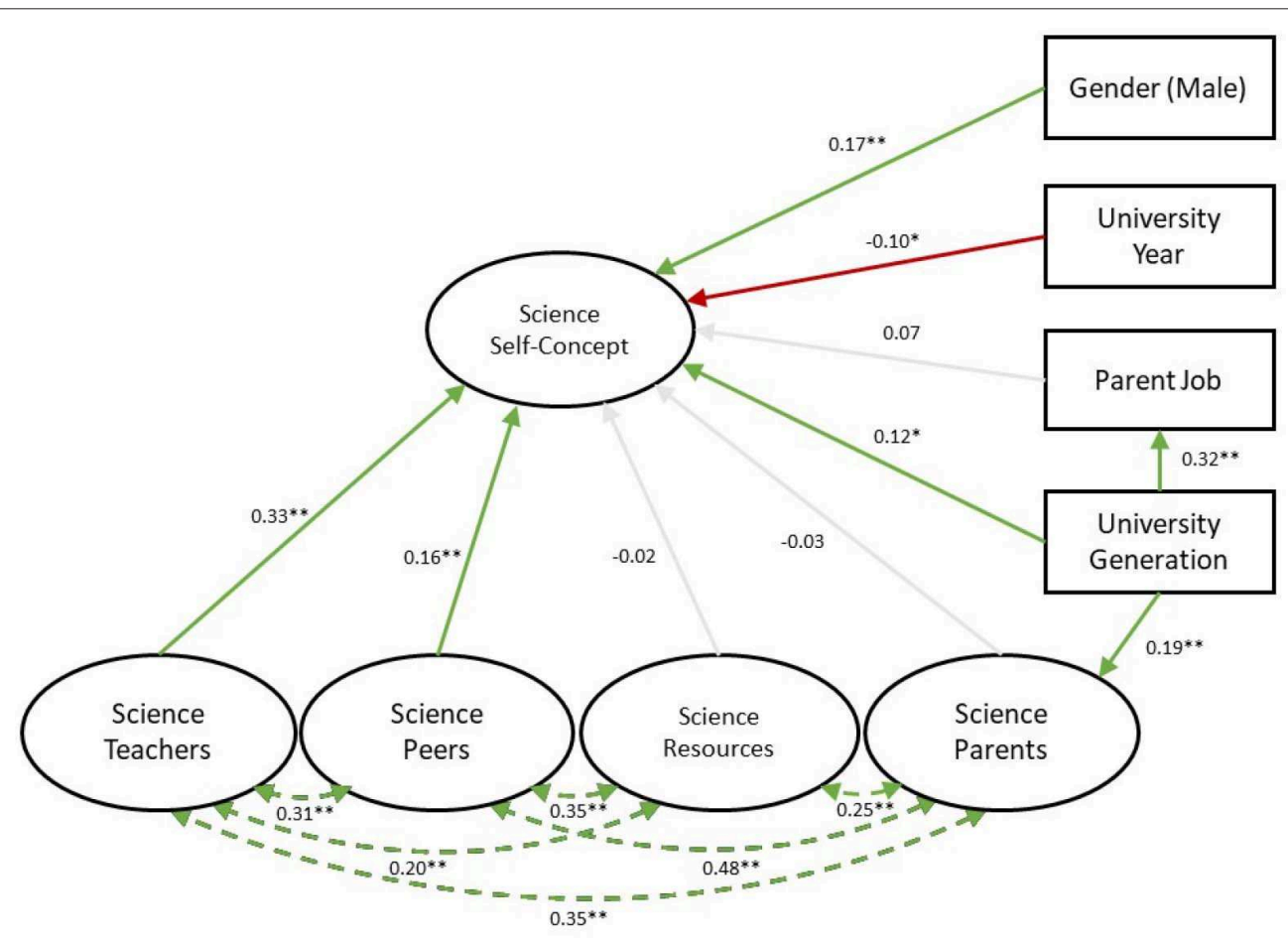

FIGURE 2 | Model results. Results with standardized coefficients and significant of the original conceptual model outlined in Figure 1. Single headed solid lines indicate a regression, while double headed dotted lines indicate a correlation. Green arrows indicate a positive association, while red indicates a negative association. Faded gray lines indicate no significant relationship. ${ }^{*} p<0.05,{ }^{* \star} p<0.001$. 
predict students' science self-concept. Results also show that male students tended to have higher levels of self-concept, and students who had attended university for more years had lower levels of self-concept. We now discuss these results in the context of university study and New Zealand science education.

Experiences with high school science teachers was the strongest predictor of science self-concept for our sample of university students. While positive experiences were linked to increased science self-concept, negative experiences predicted lower self-concept. Previous research suggests that reflected appraisals from significant others, such as those from teachers, play an important role in the way we view ourselves (Bong and Skaalvik, 2003). Tying in with Bourdieu's theory, an individual's habitus is informed by the evidence they see in the field they are participating in. Being recognized as someone who can be successful in science, by a teacher, gives students evidence that they belong. On the other hand, students who have teachers who do not appear to care about them, and who do not encourage them, may internalize the idea that science is not for them.

The current study was cross-sectional, which means that it may also be the case that students who have low self-concept in science were less likely to have been encouraged by teachers. With that being said, research shows that teachers influence the interests of their students through the support they show students across education levels (Marjoribanks, 2006). This process starts as early as primary school (Fauth et al., 2014) and through high school (Marjoribanks, 2006; Hazari et al., 2017). In the field of physics for example, the importance of being recognized as good at physics by teachers has been linked to increased intentions to pursue a career in the field (Hazari et al., 2017). Previous research also shows that students who experience high school teachers who are enthusiastic are more likely to be positively predisposed to the field (Keller et al., 2017). The current research builds on previous findings by suggesting that positive high school science teachers can positively impact on the selfconcept of their students after they leave high school and attend university. Teachers are thus integral to providing safe, inclusive educational environments that are recognized as important for young peoples' well-being (Child Wellbeing \& Poverty Reduction Group, 2019).

Peers' value of science was also positively associated with an individual science self-concept. The mechanism by which friends' value of science has an influence may be linked to social capital. As outlined by Lin (1999), the value of social capital is not just derived from knowing individuals who can provide access to a broader range of resources and a flow of information. Social capital also helps to build an individual's identity through shared group norms. As suggested by Adler and Kwon (2017, p. 29): "Strong social norms and beliefs... encourage compliance with local rules and customs". Self-concept may be boosted for students who have more opportunities to talk to others about science in general (Archer et al., 2015), while receiving increased support from friends (Bissell-Havran and Loken, 2009) and/or belonging to a network of friends at university can have positive impacts on persistence (Thomas, 2000). Through a Bourdieusian lens, having a friendship group where students can act out science safely and productively may signal to a student that they belong in science. Students without the same network of support may be less likely to persist in university study (Thomas, 2000).

It is also likely that individuals with high levels of self-concept in science seek out friends with similar interests. Homophily, the idea that "birds of a feather flock together" (McPherson et al., 2001), is a common characteristic of friendship networks. In the case of the current study, students were asked to rate the degree to which their friends think science is important, think science is cool, and care about their university grades. It may be that individuals who responded positively to these items also shared these views previously and formed friendships based on these interests. The social comparisons that students make are also an important source of self-concept (Butz and Usher, 2015). Engaging with peers who hold science in high regard and making positive social comparisons to these individuals may be a source of self-concept. Individuals with low levels of self-concept in science may avoid individuals who show great interest in science as social comparisons could make them uncomfortable (Bong and Clark, 1999). The current study is unable to untangle the direction of the relationship between science self-concept and friendship choice, but provides support for future research to investigate this area.

Parental attitudes regarding science and parental job level were found to have no significant impact on science self-concept. Given research suggests that parent-related factors may impact on adolescent students' academic self-concept (Fan and Williams, 2010), we may have expected parents value of science to also positively impact on university students' self-concept in science. However, the impact of family-related variables tends to diminish as students progress through stages of education (Holm and Jæger, 2011), and the current study specifically focused on university students which is a late educational stage. It is likely that all three of the family-related factors measured in the current study had a relatively greater impact during earlier stages of a student's educational journey. Whilst parents' value of science likely played a role in the interest that students have in science (Archer et al., 2013), parents' values are less likely to play a role in students' science self-concept judgements. The value of social capital is contingent on the context of the task that is being achieved (Adler and Kwon, 2017). As science self-concept is specific to the field of science education, it is reasonable to assume that parents' influence is not as important as teachers and peers who are active actors in the field. Parental attitudes toward science may be more predictive of early interest or engagement in science.

In contrast to the results for parental attitudes, the number of generations of a student's family that attended university was positively and significantly associated with students' science self-concept. The significance of the number of generations of the student's family who attended university may be related to Bourdieu's concept of cultural reproduction (Dimaggio, 1982). The values of parents are transmitted to their children and inform the development of habitus. Students who have university educated parents may be more likely to feel 'at home' in a university field. For first generation students, the breaking of new ground may be more confronting and challenging mentally (Gardner and Holley, 2011). In psychological terms, 
the internalization of the idea that "if my family can do it, so can I", corresponds to Bandura's (Bandura, 1986) idea of establishing self-concept through vicarious experience. Seeing someone experience success who is similar to you (i.e., family) may have an especially strong impact on self-concept. With regards to the student's habitus, vicariously experiencing success would help students internalize the idea that university is for them. Alternatively, university educated parents may also improve the academic performance of students (Paul Grayson, 2011), which in turn may influence science self-concept. Having family members who attended university is also an important form of social capital, in that it provides students with knowledge on the rules of the field, and what is needed to be successful.

The level of a student's science-related resources growing up, or objectified cultural capital, was found to be non-significant relative to the other factors included in our analysis. It may be that the resources investigated have more importance in generating early interest in science, while students in our sample were already at university. Reading about science and looking things up online about science may relate more strongly to a student's broader interests in science as opposed to their self-concept or self-belief. It may also be that students' social relationships with their teachers and peers (which both positively impacted in self-concept) ameliorate any detrimental effects that a lack of resources would have. The questionnaire items used in this study asked students to recall their access to science-related resources growing up. Future studies should seek to employ a longitudinal research design to more accurately capture the impact of resources on future self-concept in science.

Students' self-reported gender was significantly related to science self-concept, such that male students, controlling for all other factors, reported higher levels of science self-concept than female students. The lower levels of science self-concept for female students is a common finding in STEM education research (Sax et al., 2015; Ellis et al., 2016). Research has found that students (both male and female) tend to be more likely to make external attributions for a man's failure in science (i.e., the reason for failure is not due to lack of ability, but a poor test or bad luck), but are more likely to attribute women's failure to internal sources (lack of ability) (LaCosse et al., 2016).

In a Bourdieusian framework, gender differences in science self-concept can be explained in terms of a 'gendered' habitus, a variation of classed habitus (Reay, 2004). This relates to the idea that if individuals are exposed to "homogenous conditions of existence imposing homogenous conditionings" individuals will generate "homogenous systems of dispositions" (Bourdieu, 1984, p. 101). In more basic terms, if individuals are exposed to similar socio-cultural norms and environments, they may be more likely to share similar dispositions. While science has historically been a domain in which men have opportunities to succeed, women face explicit and implicit obstacles (Blickenstaff, 2005; Cheryan et al., 2017). These include pervasive negative gender stereotypes (Nosek et al., 2009), and unfair judgements regarding competency (Moss-Racusin et al., 2012; Barthelemy et al., 2016). Men may be more likely to internalize the idea that science is a domain where they belong and can perform, and this may explain why male science students are more likely to hold higher levels of self-concept in science compared to female science students. Although the effect of gender on science selfconcept was relatively small, the findings of the current study support the arguments set out by Kost-Smith et al. (2010) who suggest that the attrition of female students from STEM domains is the result of many small effects that contribute to a "smog of bias" where men are bolstered and women face obstacles.

Finally, the number of years a student reported being at university was found to negatively predict science self-concept. There is a lack of previous research investigating the temporal nature of self-concept in science at university, although one study of a mixed university sample found that academic self-concept may decrease after the first year (Isiksal, 2010). Other research has found that STEM students' self-efficacy does not decrease from first year to graduation, with it increasing for female students and remaining stable for male students (MacPhee et al., 2013). With regards to the current study, it may be that as students progress through science at university, course content becomes more challenging and thus students may be more likely to report finding science more difficult. Future research should adopt a longitudinal research design to investigate temporal changes in science self-concept in more detail.

\section{IMPLICATIONS}

The current study provides insights into factors that are related to university students' self-concept in science. The findings reported may inform researchers and policy makers on the cultural and social forms of capital that are required to produce confident learners in science. The current study finds that, for students studying science at university, the social relationships that they have are especially important.

The current study highlights the important role that high school science teachers play in boosting the self-concept of university students. Our results suggest that the impact of high school science teachers continue to be manifested in students' self-concept even after high school is finished and students have entered into university study. Given the importance of selfconcept in future achievement (Chang and Cheng, 2008; Uçar and Sungur, 2017), the results of the current study suggest that increased teacher support provides a clear method of meeting government aims for increasing the number of skilled workers in science. Massive Open Online Courses (MOOCs) are often cited as a possible solution for teacher shortages, increasing access to education when opportunities are otherwise limited. We argue that even if MOOCs are used, they must still provide students with social connections to teachers who can provide them with real, tangible feedback and recognition. The student-teacher bond should also be the targeted source of intervention to address equity issues in science (Banerjee, 2016). The expectations that teachers hold for their students may be particularly important (Rubie-Davies, 2006). Research suggests that teacher expectations are an important predictor of students transition to university study, especially for students from low SES backgrounds (Gregory and Huang, 2013). 
Our findings also suggest that social relationships with peers who hold science in high regard are linked to science self-concept. This result is especially important to consider for students who originate from social groups that are underrepresented in science and may find it more difficult to form social bonds with other students. Institutional support networks, such as Women in Science, and other community building equity programmes can play an important role in connecting underrepresented students with one another, and help to build a scaffold of peer support (Ong et al., 2018). Our results also bring attention to the need to ensure that students who are the first generation in their family to attend university are adequately supported in their learning.

\section{LIMITATIONS}

The current study, whilst providing new insights into the factors affecting self-concept of university science students in New Zealand, does have limitations that future studies should seek to address. The questionnaire, short in duration, offered insights into a select group of factors that have been found to be associated with science participation and achievement. The original questionnaire designed by DeWitt et al. (2011) had many other factors that included, but were not limited to, science aspirations, views of scientists, and parental involvement. Furthermore, given the anonymous nature of the questionnaire, it was not possible to link survey responses to administrative data that could give an indication of students' prior or future achievement, and self-reported measures of achievement contained too much missing information to be useful. Prior achievement is likely to account for much of a students' science self-concept and needs to be considered in the context of the current findings.

The sample of students who responded to the survey also display survivorship bias. These are students who have already demonstrated interest and a certain level of success in science. Our study does not account for students who dropped out of science before university. While this may be viewed as a limitation, it also focuses the current study on an asset-based framework instead of deficit models of student outcomes. Given our sample of students all demonstrated a certain level of success, we focus on factors that were particularly important for students who made the transition to university science education. Our sample and study design also allows us to identify students who are underrepresented in science based on their demographics or access to capital, but who still recorded high levels of selfconcept. A follow-up study will employ a qualitative approach to understand the experiences of these students and refine the directions of future research.

While not reported in our results, our analysis did not find sufficient evidence of measurement invariance across subject disciplines, which suggests that the constructs and relationships outlined in our conceptual model may differ for students by subject. This is not surprising, given the sample sizes per discipline and our generalized measure of science self-concept. Nevertheless, these preliminary results of the SEM suggested that, for our sample, different forms of capital may carry different value across fields, a finding inline with Bourdieu's theory. Each field has its own unique perspective on what forms of capital are valued. While the more general science related factors explored in the current study were found to be associated with a general self-concept in science, specific forms of capital may be particularly important in each science sub-field. For example, mathematics knowledge and self-efficacy in calculus may be more important for students studying in physics (Black and Hernandez-Martinez, 2016; Ellis et al., 2016). More research is needed to identify, summarize, and test the forms of capital that are valued in each science domain. We recommend more indepth and tailored questionnaires are administered to students per subject discipline.

\section{CONCLUSION}

The current study investigated the influence of science-related cultural and social capital (science capital) on the science selfconcept of undergraduate science students at the University of Auckland. A Structural Equation Model (SEM) was used to explore the relationships between a set of latent constructs defining science capital and observed measures, such as university generations in the family, parents' employment, and self-identified gender. Our theoretical model provided a good fit to our data, and gives some new insights into the relationship between science capital and science self-concept. We found that, for the students in our sample, positive experiences with high school science teachers was the most important predictor of science self-concept, whilst having peers who value science was also found to be important. Interestingly, we found that reported science-related resources and parents' value of science were not significant predictors of science self-concept, but the number of university generations in the family did have a positive association. These results provide an example of how family culture reproduced over generations may manifest as students' self-belief in the field of university science education. Finally, we also found that students who self-identified as male had higher levels of science self-concept, even after accounting for social and cultural factors in our theoretical model. We discussed these findings in the context of a growing body of research regarding equity in the field of science education, and in the context of Pierre Bourdieu's sociological theory.

\section{DATA AVAILABILITY STATEMENT}

While data analyzed for this study cannot be made publicly available due to ethics requirements (individual participants are potentially identifiable), data and the $\mathrm{R}$ code used for analysis are available on request.

\section{ETHICS STATEMENT}

The studies involving human participants were reviewed and approved by University of Auckland Human Participants Ethics Committee (UAHPEC). The patients/participants provided their written informed consent to participate in this study. 


\section{AUTHOR CONTRIBUTIONS}

ST, KM, KL, and DO'N contributed conception and design of the study. ST administered the questionnaire and organized the database, performed the statistical analysis, and wrote the first draft of the manuscript. All authors contributed to manuscript revision, read, and approved the submitted version.

\section{REFERENCES}

Adler, P. S., and Kwon, S.-w. (2017). Social capital: prospects for a new concept. Acad. Manag. Rev. 27, 17-40. doi: 10.5465/amr.2002.5922314

Archer, L., Dawson, E., DeWitt, J., Seakins, A., and Wong, B. (2015). 'Science capital': a conceptual, methodological, and empirical argument for extending bourdieusian notions of capital beyond the arts. J. Res. Sci. Teach. 52, 922-948. doi: 10.1002/tea.21227

Archer, L., DeWitt, J., Osborne, J., Dillon, J., Willis, B., and Wong, B. (2012). Science aspirations, capital, and family habitus: how families shape children's engagement and identification with science. Am. Educ. Res. J. 49, 881-908. doi: 10.3102/0002831211433290

Archer, L., Dewitt, J., and Willis, B. (2014). Adolescent boys' science aspirations: masculinity, capital, and power. J. Res. Sci. Teach. 51, 1-30. doi: $10.1002 /$ tea.21122

Archer, L., Osborne, J., and DeWitt, J. (2013). Aspires: Young People's Science and Career Aspirations, Age 10-14. London: King's College.

Aschaffenburg, K., and Maas, I. (1997). Cultural and educational careers: the dynamics of social reproduction. Am. Sociol. Rev. 62, 573-587. doi: $10.2307 / 2657427$

Bandura, A. (1986). The explanatory and predictive scope of self-efficacy theory. J. Soc. Clin. Psychol. 4, 359-373. doi: 10.1521/jscp.1986.4.3.359

Banerjee, P. A. (2016). A systematic review of factors linked to poor academic performance of disadvantaged students in science and maths in schools. Cogent Educ. 3:1178441. doi: 10.1080/2331186X.2016.1178441

Barthelemy, R. S., McCormick, M., and Henderson, C. (2016). Gender discrimination in physics and astronomy: graduate student experiences of sexism and gender microaggressions. Phys. Rev. Phys. Educ. Res. 12, 1-14. doi: 10.1103/PhysRevPhysEducRes.12.020119

Bernstein, B. (1971). Class, Codes and Control, Vol. 1. London: Routledge \& Kegan Paul.

Bissell-Havran, J. M., and Loken, E. (2009). The role of friends in early adolescents' academic self-competence and intrinsic value for math and english. J. Youth Adolesc. 38, 41-50. doi: 10.1007/s10964-007-9266-3

Black, L., and Hernandez-Martinez, P. (2016). Re-thinking science capital: the role of 'capital' and 'identity' in mediating students' engagement with mathematically demanding programmes at university. Teach. Math. Appl. 35, 131-143. doi: 10.1093/teamat/hrw016

Blanden, J., and Gregg, P. (2004). Family income and educational attainment: a review of approaches and evidence for britain. Oxford Rev. Econ. Policy 20, 245-263. doi: 10.1093/oxrep/grh014

Blickenstaff, J. C. (2005). Women and science careers: leaky pipeline or gender filter? Gender Educ. 17, 369-386. doi: 10.1080/09540250500145072

Bodovski, K. (2014). Adolescents' emerging habitus: the role of early parental expectations and practices. Brit. J. Sociol. Educ. 35, 389-412. doi: 10.1080/01425692.2013.776932

Bong, M., and Clark, R. E. (1999). Comparison between self-concept and self-efficacy in academic motivation research. Educ. Psychol. 34, 139-153. doi: 10.1207/s15326985ep3403_1

Bong, M., and Skaalvik, E. M. (2003). Academic self-concept and selfefficacy: how different are they really? Educ. Psychol. Rev. 15, 1-40. doi: 10.1023/A:1021302408382

Bourdieu, P. (1977). Outline of a Theory of Practice, Vol. 16. Cambridge, UK: Cambridge University Press.

Bourdieu, P. (1984). Distinction: A Social Critique of the Judgement of Taste. Routledge. Cambridge, MA: Harvard University Press.

\section{FUNDING}

ST was supported by a University of Auckland Doctoral Scholarship (https://www.auckland.ac.nz/en.html). DO'N received funding from Te Pūnaha Matatini (https://www. tepunahamatatini.ac.nz/) grant number UOA 9167-3705716. The funders had no role in study design, data collection and analysis, decision to publish, or preparation of the manuscript.

Bourdieu, P. (1986). "The forms of capital," in Handbook of Theory and Research for the Sociology of Education, chapter 2, ed J. Richardson (Westport, CT: Greenwood Publishing Group), 47-58.

Bourdieu, P., and Wacquant, L. J. (1992). An invitation to Reflexive Sociology. Chicago, IL: University of Chicago Press.

Brown, B. B., Clasen, D. R., and Eicher, S. A. (1986). Perceptions of peer pressure, peer conformity dispositions, and self-reported behavior among adolescents. Dev. Psychol. 22:521. doi: 10.1037/0012-1649.22.4.521

Butz, A. R., and Usher, E. L. (2015). Salient sources of early adolescents' self-efficacy in two domains. Contemp. Educ. Psychol. 42, 49-61. doi: 10.1016/j.cedpsych.2015.04.001

Buuren, S. V., and Groothuis-Oudshoorn, K. (2010). mice: multivariate imputation by chained equations in r. J. Stat. Softw. 45, 1-68. doi: 10.18637/jss.v045.i03

Campbell, D. T., and Fiske, D. W. (1959). Convergent and discriminant validation by the multitrait-multimethod matrix. Psychol. Bull. 56:81. doi: $10.1037 / \mathrm{h} 0046016$

Carolan, B. V., and Wasserman, S. J. (2015). Does parenting style matter? concerted cultivation, educational expectations, and the transmission of educational advantage. Sociol. Perspect. 58, 168-186. doi: 10.1177/0731121414562967

Chang, C.-Y., and Cheng, W.-Y. (2008). Science achievement and students' selfconfidence and interest in science: a taiwanese representative sample study. Int. J. Sci. Educ. 30, 1183-1200. doi: 10.1080/09500690701435384

Cheadle, J. E., and Amato, P. R. (2011). A quantitative assessment of lareau's qualitative conclusions about class, race, and parenting. J. Fam. Issues 32, 679-706. doi: 10.1177/0192513X10386305

Cheryan, S., Ziegler, S. A., Montoya, A. K., and Jiang, L. (2017). Why are some stem fields more gender balanced than others? Psychol. Bull. 143:1. doi: $10.1037 /$ bul0000052

Child Wellbeing \& Poverty Reduction Group (2019). Child and Youth Wellbeing Strategy. Wellington: Child Wellbeing \& Poverty Reduction Group.

Chyung, S. Y., Swanson, I., Roberts, K., and Hankinson, A. (2018). Evidencebased survey design: the use of continuous rating scales in surveys. Performan. Improvem. 57, 38-48. doi: 10.1002/pfi.21763

Dalgety, J., and Coll, R. K. (2006). Exploring first-year science students' chemistry self-efficacy. Int. J. Sci. Math. Educ. 4, 97-116. doi: 10.1007/s10763-0051080-3

Dawson, E. (2014). "Not designed for us": how science museums and science centers socially exclude low-income, minority ethnic groups. Sci. Educ. 98, 981-1008. doi: 10.1002/sce.21133

DeWitt, J., Archer, L., Osborne, J., Dillon, J., Willis, B., and Wong, B. (2011). High aspirations but low progression: the science aspirations-careers paradox amongst minority ethnic students. Int. J. Sci. Math. Educ. 9, 243-271. doi: 10.1007/s10763-010-9245-0

Dimaggio, P. (1982). Cultural capital and school success: the impact of status cutlure participation on the grades of U.S. high school students. Am. Sociol. Rev. 47, 189-201. doi: 10.2307/2094962

Douvan, E. A. M., Douvan, E., and Adelson, J. (1966). The Adolescent Experience. New York, NY: Wiley.

Dumais, S. A. (2002). Cultural capital, gender, and school success: the role of habitus. Sociol. Educ. 75:44. doi: 10.2307/3090253

Edgerton, J. D., Peter, T., and Roberts, L. W. (2014). Gendered habitus and gender differences in academic achievement. Alberta J. Educ. Res. 60, 182-212.

Ellis, J., Fosdick, B. K., and Rasmussen, C. (2016). Women 1.5 times more likely to leave STEM pipeline after calculus compared to men: lack of mathematical confidence a potential culprit. $\{P L O S\}\{O N E\}$ 11:e0157447. doi: 10.1371/journal.pone.0157447 
Else-Quest, N. M., Mineo, C. C., and Higgins, A. (2013). Math and science attitudes and achievement at the intersection of gender and ethnicity. Psychol. Women Q. 37, 293-309. doi: 10.1177/0361684313480694

Fan, W., and Williams, C. M. (2010). The effects of parental involvement on students' academic self-efficacy, engagement and intrinsic motivation. Educ. Psychol. 30, 53-74. doi: 10.1080/01443410903353302

Fauth, B., Decristan, J., Rieser, S., Klieme, E., and Büttner, G. (2014). Student ratings of teaching quality in primary school: dimensions and prediction of student outcomes. Learn. Instruct. 29, 1-9. doi: 10.1016/j.learninstruc.2013.07.001

Field, A., Miles, J., and Field, Z. (2012). Discovering Statistics Using R. Thousand Oaks, CA: Sage publications.

Gardner, S. K., and Holley, K. A. (2011). "those invisible barriers are real": the progression of first-generation students through doctoral education. Equity Excell. Educ. 44, 77-92. doi: 10.1080/10665684.2011.529791

Gibb, S. J., Fergusson, D. M., and Horwood, L. J. (2012). Childhood family income and life outcomes in adulthood: findings from a 30year longitudinal study in new zealand. Soc. Sci. Med. 74, 1979-1986. doi: 10.1016/j.socscimed.2012.02.028

Goldhaber, D. D., and Brewer, D. J. (2000). Does teacher certification matter? high school teacher certification status and student achievement. Educ. Eval. Policy Anal. 22, 129-145. doi: 10.3102/01623737022002129

Gregory, A., and Huang, F. (2013). It takes a village: the effects of 10th grade college-going expectations of students, parents, and teachers four years later. Am. J. Commun. Psychol. 52, 41-55. doi: 10.1007/s10464-013-9575-5

Hasson, D., and Arnetz, B. B. (2005). Validation and findings comparing vas vs. likert scales for psychosocial measurements. Int. Electr. J. Health Educ. 8, $178-192$.

Hattie, J. (2014). Self-concept. Hove: Psychology Press.

Hazari, Z., Brewe, E., Goertzen, R. M., and Hodapp, T. (2017). The importance of high school physics teachers for female students' physics identity and persistence. Phys. Teacher 55, 96-99. doi: 10.1119/1.4974122

Hikuroa, D. (2017). Mātauranga māori-the ūkaipō of knowledge in new zealand. J. R. Soc. New Zealand 47, 5-10. doi: 10.1080/03036758.2016.1252407

Holm, A., and Jæger, M. M. (2011). Dealing with selection bias in educational transition models: the bivariate probit selection model. Res. Soc. Stratificat. Mobil. 29, 311-322. doi: 10.1016/j.rssm.2011.02.002

Hu, L.-T., and Bentler, P. M. (1999). Cutoff criteria for fit indexes in covariance structure analysis: conventional criteria versus new alternatives. Struct. Equat. Model. 6, 1-55. doi: 10.1080/10705519909540118

Huber, P. J. (1967). "The behavior of maximum likelihood estimates under nonstandard conditions," in Proceedings of the Fifth Berkeley Symposium on Mathematical Statistics and Probability, Vol. 1 (Berkeley; Los Angeles, CA: University of California Press), 221-233.

Isiksal, M. (2010). A comparative study on undergraduate students' academic motivation and academic self-concept. Span. J. Psychol. 13, 572-585. doi: $10.1017 /$ S1138741600002250

Jansen, M., Scherer, R., and Schroeders, U. (2015). Students' self-concept and self-efficacy in the sciences: differential relations to antecedents and educational outcomes. Contemp. Educ. Psychol. 41, 13-24. doi: 10.1016/j.cedpsych.2014.11.002

Jorgensen, T. D., Pornprasertmanit, S., Schoemann, A., Rosseel, Y., Miller, P., Quick, C., et al. (2018). Package 'semTools'.

Keller, M. M., Neumann, K., and Fischer, H. E. (2017). The impact of physics teachers' pedagogical content knowledge and motivation on students' achievement and interest. J. Res. Sci. Teach. 54, 586-614. doi: 10.1002/tea.21378

Kost-Smith, L. E., Pollock, S. J., and Finkelstein, N. D. (2010). Gender disparities in second-semester college physics: the incremental effects of a 'Smog of Bias'. Phys. Rev. Spec. Top. Phys. Educ. Res. 6, 1-17. doi: 10.1103/PhysRevSTPER.6.020112

LaCosse, J., Sekaquaptewa, D., and Bennett, J. (2016). \{STEM $\}$ stereotypic attribution bias among women in an unwelcoming science setting. Psychol. Women Q. 40, 378-397. doi: 10.1177/0361684316630965

Lareau, A. (2011). Unequal Childhoods: Class, Race, and Family Life. Berkeley, CA: Univ of California Press.

Larson, L. M., Pesch, K. M., Surapaneni, S., Bonitz, V. S., Wu, T.-F., and Werbel, J. D. (2015). Predicting graduation: the role of mathematics/science self-efficacy. J. Career Assessm. 23, 399-409. doi: 10.1177/1069072714547322
Lin, N. (1999). Building a network theory of social capital. Connections 22, 28-51.

Little, R. J. (1988). Missing-data adjustments in large surveys. J. Bus. Econ. Stat. 6 , 287-296. doi: 10.1080/07350015.1988.10509663

Lyons, T. (2006). "Choosing physical science courses: the importance of cultural and social capital in the enrolment decisions of high achieving students," in Science and Technology Education for a Diverse World: Dilemmas, Needs and Partnerships, eds R. Janiuk, and E. Samonek-Miciuk (Lubin: Marie CurieSklodowska University Press), 369-384.

MacPhee, D., Farro, S., and Canetto, S. S. (2013). Academic self-efficacy and performance of underrepresented stem majors: gender, ethnic, and social class patterns. Anal. Soc. Issues Public Policy 13, 347-369. doi: 10.1111/asap.12033

Mahoney, P., Park, Z., and Smyth, R. (2013). Moving on Up: What Young People Earn After Their Tertiary Education. Wellington: Tertiary Sector Performance Analysis.

Marjoribanks, K. (2006). Adolescents' cognitive habitus, learning environments, affective outcomes of schooling, and young adults' educational attainment. Educ. Psychol. 26, 229-250. doi: 10.1080/01443410500344233

Marsh, H. W. (2014). “Academic self-concept: theory, measurement, and research," in Psychological Perspectives on the Self, Vol 4, ed J. Suls (New York, NY: Psychology Press), 71-110.

McPherson, M., Smith-Lovin, L., and Cook, J. M. (2001). Birds of a feather: homophily in social networks. Annu. Rev. Sociol. 27, 415-444. doi: 10.1146/annurev.soc.27.1.415

Meehan, L., Pacheco, G., and Pushon, Z. (2017). Explaining Ethnic Disparities in Bachelor's Qualifications: Participation, Retention and Completion in New Zealand. Technical report, New Zealand Productivity Commission, Wellington.

Ministry of Education (2007). The New Zealand Curriculum. Wellington: Ministry of Education.

Moakler, M. W. Jr., and Kim, M. M. (2014). College major choice in stem: revisiting confidence and demographic factors. Career Dev. Q. 62, 128-142. doi: 10.1002/j.2161-0045.2014.00075.x

Moss-Racusin, C. A., Dovidio, J. F., Brescoll, V. L., Graham, M. J., and Handelsman, J. (2012). Science faculty's subtle Gender biases favor male students. Proc. Natl. Acad. Sci. U.S.A. 109, 16474-16479. doi: 10.1073/pnas.1211286109

$\mathrm{Mu}$, G. M. (2014). Heritage language learning for chinese australians: the role of habitus. J. Multilingual Multicult. Dev. 35, 497-510. doi: 10.1080/01434632.2014.882340

Mujtaba, T., Sheldrake, R., Reiss, M. J., and Simon, S. (2018). Students' science attitudes, beliefs, and context: associations with science and chemistry aspirations. Int. J. Sci. Educ. 40, 644-667. doi: 10.1080/09500693.2018. 1433896

Murphy, P. (2018). "Determinants of success in learning mathematics: a study of post-secondary students in New Zealand," in Mathematics Education Research Group of Australasia, Manukau.

Nash, R. (1999). Bourdieu, 'habitus', and educational research: is it all worth the candle? Brit. J. Sociol. Educ. 20, 175-187. doi: 10.1080/01425699995399

Norton, A., and Cherastidtham, I. (2016). Mapping Australian Higher Education. Technical Report 2014-15, Grattan Institute Melbourne, Melbourne, VIC.

Nosek, B. A., Smyth, F. L., Sriram, N., Lindner, N. M., Devos, T., Ayala, A., et al. (2009). National differences in gender-science stereotypes predict national sex differences in science and math achievement. Proc. Natl. Acad. Sci. U.S.A. 106, 10593-10597. doi: 10.1073/pnas.0809921106

Ong, M. (2005). Body projects of young women of color in physics: intersections of gender, race, and science. Soc. Probl. 52, 593-617. doi: 10.1525/sp.2005.52.4.593

Ong, M., Smith, J. M., and Ko, L. T. (2018). Counterspaces for women of color in stem higher education: marginal and central spaces for persistence and success. J. Res. Sci. Teach. 55, 206-245. doi: 10.1002/tea.21417

Oreopoulos, P. (2007). Do dropouts Drop out too Soon? Wealth, health and happiness from compulsory schooling. J. Public Econ. 91, 2213-2229. doi: 10.1016/j.jpubeco.2007.02.002

Osborne, J., Simon, S., and Collins, S. (2003). Attitudes towards science: a review of the literature and its implications. Int. J. Sci. Educ. 25, 1049-1079. doi: 10.1080/0950069032000032199

Ost, B. (2010). The role of peers and grades in determining major persistence in the sciences. Econ. Educ. Rev. 29, 923-934. doi: 10.1016/j.econedurev.2010. 06.011 
Paul Grayson, J. (2011). Cultural capital and academic achievement of first generation domestic and international students in canadian universities. Brit. Educ. Res. J. 37, 605-630. doi: 10.1080/01411926.2010.487932

Peters, M. L. (2013). Examining the relationships among classroom climate, selfefficacy, and achievement in undergraduate mathematics: a multi-level analysis. Int. J. Sci. Math. Educ. 11, 459-480. doi: 10.1007/s10763-012-9347-y

Potvin, G., and Hazari, Z. (2016). Student evaluations of physics teachers: on the stability and persistence of gender bias. Phys. Rev. Phys. Educ. Res. 12, 1-9. doi: 10.1103/PhysRevPhysEducRes.12.020107

Pricewaterhouse Coopers Australia (2015). A Smart Move: Future-Proofing Australia's Workforce by Growing Skills in Science, Technology, Engineering and Maths (STEM). Technical report, Pricewaterhouse Coopers Australia, Sydney, NSW.

R Core Team (2013). R: A Language and Environment for Statistical Computing. Vienna: R Core Team.

Reay, D. (2004). 'It's all becoming a habitus': beyond the habitual use of habitus in educational research. Brit. J. Sociol. Educ. 25, 431-444. doi: 10.1080/0142569042000236934

Reynolds, J. R., and Johnson, M. K. (2011). Change in the stratification of educational expectations and their realization. Soc. Forces 90, 85-109. doi: $10.1093 /$ sf $/ 90.1 .85$

Robnett, R. D., and Leaper, C. (2013). Friendship groups, personal motivation, and gender in relation to high school students' stem career interest. J. Res. Adolesc. 23, 652-664. doi: 10.1111/jora.12013

Rosenberg, M. (1979). Conceiving the Self. New York, NY: Basic.

Rosseel, Y. (2012). Lavaan: an $\mathrm{r}$ package for structural equation modeling and more. version 0.5-12 (beta). J. Stat. Softw. 48, 1-36. doi: 10.18637/jss.v048.i02

Rubie-Davies, C. M. (2006). Teacher expectations and student self-perceptions: exploring relationships. Psychol. Schools 43, 537-552. doi: 10.1002/pits.20169

Rubin, D. B. (2004). Multiple Imputation for Nonresponse in Surveys, Vol. 81. New Jersey, NJ: John Wiley \& Sons.

Ryan, A. M. (2000). Peer groups as a context for the socialization of adolescents' motivation, engagement, and achievement in school. Educ. Psychol. 35, 101111. doi: 10.1207/S15326985EP3502_4

Sax, L. J., Kanny, M. A., Riggers-Piehl, T. A., Whang, H., and Paulson, L. N. (2015). "but i'm not good at math": the changing salience of mathematical self-concept in shaping women's and men's stem aspirations. Res. Higher Educ. 56, 813-842. doi: 10.1007/s11162-015-9375-x

Schreiber, J. B., Nora, A., Stage, F. K., Barlow, E. A., and King, J. (2006). Reporting structural equation modeling and confirmatory factor analysis results: a review. J. Educ. Res. 99, 323-338. doi: 10.3200/JOER.99.6.323-338

Shapiro, T., Meschede, T., and Osoro, S. (2013). "The widening racial wealth gap," in The Assets Perspective, eds R. Cramer and T. Shanks (New York, NY: Palgrave Macmillan), 1-8.

Shavelson, R. J., Hubner, J. J., and Stanton, G. C. (1976). Self-concept: validation of construct interpretations. Rev. Educ. Res. 46, 407-441. doi: $10.3102 / 00346543046003407$
Siegle, D., and McCoach, D. B. (2007). Increasing student mathematics self-efficacy through teacher training. J. Adv. Acad. 18, 278-312.

Steiger, J. H. (2007). Understanding the limitations of global fit assessment in structural equation modeling. Pers. Individ. Diff. 42, 893-898. doi: 10.1016/j.paid.2006.09.017

Thomas, S. L. (2000). Ties that bind: a social network approach to understanding student integration and persistence. J. High. Educ. 71, 591-615. doi: 10.1080/00221546.2000.11778854

Tighezza, M. (2014). Modeling relationships among learning, attitude, selfperception, and science achievement for grade 8 saudi students. Int. J. Sci. Math. Educ. 12, 721-740. doi: 10.1007/s10763-013-9426-8

Tomanović, S. (2004). Family habitus as the cultural context for childhood. Childhood 11, 339-360. doi: 10.1177/0907568204044887

Traweek, S. (2009). Beamtimes and Lifetimes. Cambridge, MA: Harvard University Press.

Turnbull, S., Locke, K., Vanholsbeeck, F., and O’Neale, D. (2019). Bourdieu, networks, and movements: using the concepts of habitus, field and capital to understand a network analysis of gender differences in undergraduate physics. PLoS ONE 14:e0222357. doi: 10.1371/journal.pone.0222357

Uçar, F. M., and Sungur, S. (2017). The role of perceived classroom goal structures, self-efficacy, and engagement in student science achievement. Res. Sci. Technol. Educ. 35, 149-168. doi: 10.1080/02635143.2017.1278684

Walker, S., Eketone, A., and Gibbs, A. (2006). An exploration of kaupapa maori research, its principles, processes and applications. Int. J. Soc. Res. Methodol. 9, 331-344. doi: 10.1080/13645570600916049

Wayne, A. J., and Youngs, P. (2003). Teacher characteristics and student achievement gains: a review. Rev. Educ. Res. 73, 89-122. doi: 10.3102/00346543073001089

White, H. (1982). Maximum likelihood estimation of misspecified models. Econometrica 50, 1-25. doi: 10.2307/1912526

Wong, B. (2016). Science Education, Career Aspirations and Minority Ethnic Students. London, UK: Palgrave Macmillan.

Wu, C.-L., and Bai, H. (2015). From early aspirations to actual attainment: the effects of economic status and educational expectations on university pursuit. High. Educ. 69, 331-344. doi: 10.1007/s10734-014-9778-1

Conflict of Interest: The authors declare that the research was conducted in the absence of any commercial or financial relationships that could be construed as a potential conflict of interest.

Copyright (C) 2020 Turnbull, Meissel, Locke and O'Neale. This is an open-access article distributed under the terms of the Creative Commons Attribution License (CC $B Y)$. The use, distribution or reproduction in other forums is permitted, provided the original author(s) and the copyright owner(s) are credited and that the original publication in this journal is cited, in accordance with accepted academic practice. No use, distribution or reproduction is permitted which does not comply with these terms. 